\title{
Performance, poverty and urban development: Kigali's motari and the spectacle city
}

\author{
William Rollason \\ Department of Anthropology, School of Social Sciences, Brunel University, \\ United Kingdom
}

\begin{abstract}
In this paper I explore tensions and conflicts over poverty reduction and urban development in Kigali, Rwanda's capital in terms of theories of performativity. On one hand, motorcycle taxis offer large numbers of young men good livelihoods - reflecting the government of Rwanda's stated commitment to poverty reduction, especially amongst youth; on the other, motorcycle taxi drivers suffer harassment at the hands of city authorities and police, who are keen to eradicate motorcycle taxis from the urban scene altogether. I interpret this tension as a conflict over the appropriate performance of development in the city; I argue that in pursuit of urban development, the city itself becomes an image, projected in order to attract the investment which will give body to the simulated spectacle that Kigali present. Conflicts between the city and motorcycle taxi drivers erupt because motorcycle taxis cannot perform to the aesthetic standards of the new Kigali. In conclusion, I suggest that the rendition of Kigali's development as image has broader lessons for studies of development in general. Specifically, these conflicts expose the operation of images and their performance as political resources, conferring intelligibility and legitimacy in the spectacle of national development.
\end{abstract}

Key words: Rwanda, poverty reduction, urban development, performativity

\section{Introduction}

Poverty reduction is a stated aim of Rwanda's current regime, under the leadership of the Rwandan Patriotic Front (RPF), victors of the civil war of 1990-94. The government's commitment to poverty reduction is contained in the Economic Development and Poverty Reduction Strategy (Republic of Rwanda, 2007a). This document is the successor of an earlier Poverty Reduction Strategy Paper (National Poverty Reduction Programme, 2002); Rwanda, widely lauded as a model developmental state, was an early adopter of poverty reduction as a development strategy when it became the orthodoxy of the World Bank at the turn of the century (Craig \& Porter, 2003).

EDPRS envisages fulfilling two sets of goals. The first of these is defined by the ambitious long-term strategy document, Vision 2020 (Republic of Rwanda, 2000). Vision 2020 envisages Rwanda becoming a middle income country by 2020, a feat which will 
require the maintenance of GDP growth at $7 \%$ over the two decades which the strategy covers. Vision 2020 lays out a plan to achieve this goal through private sector development and foreign investment in a knowledge-based service economy. This is expected to involve massive urbanisation, both as an effect of commercialising agriculture, and as a driver of economic growth in the new knowledge-economy. The second set of objectives is defined by the Millennium Development Goals and therefore involves quantifiable and multi-dimensional poverty reduction targets.

In this paper I examine the issue of poverty reduction in Rwanda critically through an analysis of the relationship between Kigali's motorcycle taxi drivers and 'state authorities'. 'This analysis is based on eight months of ethnographic fieldwork between January and September 2012 with motorcycle taxi drivers in Nyarungenge district. This was based on participant observation amongst drivers at work and at home, including 62 interviews with these men, and further interviews with officials involved in the transport sector of the city, in the motorcyclists' organisations and the police. Interviews with motorcyclists, and participant observation yielded large quantities of qualitative data.

While I wish to stress that the interpretations here are mine alone, and do not directly reflect the views of any individual, it is important to recognise that motorcyclists were keen to tell their stories. Although in many cases, their views were at odds with official narratives about development in Rwanda - and therefore might place them at risk of reprisals - many of my close collaborators and friends urged me to write about what they told me and not to be concerned with the consequences, which they understood better than I and knew how to deal with. Of course, I am deeply concerned with the consequences of criticism for the men who helped me, but at the same time, in the spirit of their engagement with my project, I present here an account based on the critical perspectives motorcyclists articulated to me. This is of course an interested account, and especially at certain junctures - importantly in relation to the City Council and to security - will lack the balance of sociological detachment; they are presented in the spirit of enquiry and debate, not political criticism or defamation (c.f. Sommers, 2012).

On the basis of my field data, I show how motorcyclists, who might be expected to be very vulnerable to poverty, in fact make a relatively good and stable livelihood. Despite the success of the sector, however, motorcycle taxi drivers suffer harassment at the hands of city authorities and police, who plan to eradicate motorcycle taxis from the urban scene altogether. This policy appears to present a contradiction in the context of Rwanda's stated commitment to poverty reduction and the particular challenges of employment and livelihood amongst urban youth.

I argue that this contradiction can be resolved if we reject the idea that 'development' in Rwanda is closely connected to material-economic referents; that is, that there is

In Rwanda, the distinction between state and non-state bodies is difficult to draw because of the interpenetration of the ruling party and the state and the mobilisation of thousands of ordinary people as low-level voluntary functionaries (Purdeková, 2011). These are not new features of Rwandan politics, but were widely noted before the civil war bought the RPF to power (Gready, 2010; Uvin, 1998, 2001). 'The authorities' are therefore often difficult to identify and many of my informants regarded the relationship between co-operatives, local government, the police and perhaps some of their colleagues to be seamless. 
something about 'development' as a symbolic form, or sign, which prevents the material fact of 'poverty reduction' qua increased income among the poor directly or straightforwardly contributing to 'development'. ${ }^{2}$ After outlining the sociological character of the motorcycle taxi sector in Kigali, I address this conundrum in the context of the redevelopment of Kigali, currently underway under the Kigali Conceptual Masterplan (Oz Architecture and Kigali City Council, 2007) - a sweeping project for change in the city mandated by EDPRS and Vision 2020, in which almost every built structure extant in 2007 is slated for replacement. Any issue pertaining to development in Kigali must be seen in terms of this plan. My analysis of the apparent contradiction between motorcyclists' success in escaping poverty, and official hostility towards them is based on three observations related to this plan. First, that urban development in general can be regarded as an exercise in image-creation rather than primarily concerned with actual urban life. I draw on the work of James Scott (1998) and David Harvey (1989), amongst others to support this claim. Second, this trend is noted particularly in African urban development, in which models of efficient cities, not detailed knowledge of African urban life, define success. Here I draw on the work of social geographers, notably Rakodi (2006) and Simone (2004). Third, that the significance of images and performances of development is likely to be considerable in Rwanda, whose government is widely seen to attend more to the rhetorical presentation of policy than to the realities of its implementation. Ingaleare's recent work on gacaca courts supports this argument strongly (Ingelaere, 2012; see also Pottier, 2002).

On the basis of these three observations, I argue that the redevelopment of Kigali City can be seen as 'performative' in the sense defined by Judith Butler (1990), drawing on Austin's (1975) theory of performative speech acts. That is, it is an enactment which does not proceed from a prior 'reality', but which, through the imagery it projects, invokes a reality that is parsed from it. In simple terms, I am arguing that the 'development' of Kigali has less to do with the actual livelihoods of its residents than with the appearance of modernity, from which 'development' is read as a secondary effect, independent of any actual results in terms of poverty reduction. Motorcyclists 'poverty reduction' activity is not recognised as development as it does not fit these images, but becomes something anti-social, paradoxically inimical to the developmental state. Analysing this conflict in terms of the images presented by and as urban development in Kigali suggests that the relationship between motorcyclists and development in Rwanda is established in performative terms through their capacity to comply with images and gestures which would grant what they do intelligibility and legitimacy (Butler, 1990, 1995a, 1995b; see review in Stern, 2000) in the spectacle of national development (Harvey, I989; Scott, I998).

Because of the form of the argument, I avoid defining 'development' as an ideal-type against which to judge whether Rwanda 'really' has development or not. This is not the point I am trying to make. What I am attempting to suggest is how imageries locally regarded as development and figured in the city work against poverty reduction (which I take to mean a material increase in incomes and living standards amongst the poor, or those at risk of poverty, according to the definitions provided in EDPRS and derived from the Millenium Development Goals), introducing the contradiction I describe. The exclusionary potential of development imagery is my target, not the economic effectiveness it might or might not have. 
In conclusion, I briefly suggest that the rendition of Kigali's development as image has broader lessons for studies of development in general.

\section{The moto sector in Kigali}

Kigali, the capital of Rwanda, is served by large numbers of motorcycle taxis, taximoto or simply moto. Data from the official organisations of motorcycle taxis show 10,466 motos operating in the city. ${ }^{3}$ Motos are popular for many reasons: they are fast, capable of negotiating standing traffic, and while they are certainly the most dangerous form of public transport available in Kigali, they run at night after bus services have stopped and on roads impassable to other vehicles. The moto sector has grown markedly with Rwanda's recent strong economic performance, and a recent streamlining of driving tests (Asiimwe, 2012): there are almost 300\% more licensed motos on the road today than there were three years ago (Rwanda Utilities Regulatory Agency, 20II), although drivers thought that this growth was partly attributable to a stricter licensing regime leading previously illegal riders to register themselves...

Taxi-motos are driven by motari. Motari are almost exclusively men. The vast bulk are young, falling into the Rwandan government's definition of youth (National Institute of Statistics, 2012a; Sommers, 2012) - people between I4 and 35 years of age, a group which constitutes $76 \%$ of the national population (National Institute of Statistics, 201 $2 \mathrm{~b}$ ). While a few men were in their forties, or even their fifties, drivers thought that the physical demands of driving a motorcycle for long hours made the business of driving moto, the ikimotari ('the thing of the motorcyclists'), a 'young man's game'. Many of the motari working in Kigali, perhaps $50 \%$ or more, are migrants or commuters to the urban area. ${ }^{4}$ A majority of migrants come from Southern Province, Rwanda's most impoverished area (National Institute of Statistics, 2012c). ${ }^{5}$ While motari come from many walks of life ex-convicts, ex-soldiers, houseboys, university students, businessmen or drivers down on their luck - they are not on the whole a well-educated group. Few have passed beyond primary school and a substantial minority are not functionally literate. In many ways, motari are representative of Rwanda's youth.

The moto sector in Rwanda is much more tightly regulated than in neighbouring countries. All motari in Rwanda are members of co-operative or syndicate organisations. In Kigali, two such organisations operate, the Federation Rwandaise des Convoyeurs

I am grateful to FERWACOTAMO and SYTRAMORWA for granting me access to this data.

4 The extent of the administrative district of Kigali was expanded at the time of the nationwide administrative reforms associated with decentralisation, in 2006. As a result of these reforms, provincial boundaries were redrawn and the number of provinces reduced from 12 to five. Kigali City Province incorporated parts of Kigali Ngali (Kigali Rural). Many migrants from the rural fringes of the city still identify themselves as coming from Kigali Rural.

5 Southern Province appears to be the origin of at least a large minority of migrants to Kigali. Current government socio-economic statistics do not capture the geographical origins of migrants to Kigali, focusing instead on whether they originate in rural or urban areas. However, the first household survey of 2000-or did collect this data and shows that Southern Province, still the poorest region of the country, supplied the largest share of the city's migrants. Half of the migrants interviewed for this research came from Southern Province. 
du Taxi-Moto (FERWACOTAMO), and the smaller Syndicate of Taxi-Motos of Rwanda (SYTRAMORWA). ${ }^{6}$ Most importantly, these two bodies provide 'security' (umutekano) in the sector. This means, ensuring that motari are properly documented and licensed, and guaranteeing their identity by means of numbered jackets and the development of databases containing the details of all riders and their machines. They also have a limited role in the economic and social development of motari.

In co-operation with Kigali City Council (KCC) and the national police, the motorcyclists' organisations have succeeded in reforming a sector widely viewed to have been lawless and dangerous as recently as the mid-20oos (Goodfellow \& Smith, 2013). The quality of that co-operation is varied and contextual. However, it is clear that both the police and specific departments within KCC - notably for Infrastructure and Youth, Culture and Sport - have close relationships with the motorcyclists' organisations, integrating them as informal extensions of their own mechanisms of surveillance and downward policy communication or 'sensitisation' (c.f. Purdeková, 20II). ${ }^{7}$ This collaboration has been effective in making changes to the moto sector. Today, it is rare to find a motari who does not provide a passenger with a helmet, who has no driving license, or who is willing to carry multiple passengers. ${ }^{8}$

The tight regulation of the ikimotari is typical of government attempts to formalise sectors of the informal economy, and relates strongly to the recent history of war, genocide and precarious reconstruction in the country. While it is impossible to do justice to the enormous literature on the subject here, it is important to recognise the impact of the past on contemporary Rwanda. A strong governmental system, deeply penetrating 'civil

6 FERWACOTAMO and SYTRAMORWA are competing organisations, set up on different legislative bases, and under the tutelage of different ministries. FERWACOTAMO is a federation of co-operatives established under the 2007 Law of Cooperatives (Republic of Rwanda, 2007b), which reports to the Rwanda Cooperatives Agency under the authority of the Ministry of Economics and Finance. SYTRAMORWA is a syndicate (trade union) organisation established under regulations overseen by the Ministry of Labour.

7 These relationships of collaboration might be viewed as 'segmentary' - close to the apex of their organisational structures, both SYTRAMORWA and FERWACOTAMO have close links to KCC, but are more differentiated at lower levels. Hence, the leadership of both organisations, but especially SYTRAMORWA, whose president was connected to a corruption scandal involving the City's department for Youth, Culture and Sport in late 2012 (Kimenyi, 2012), have intimate relationships with KCC departments and the Traffic Police, acting for them in safety and sensitisation campaigns. Co-operative branches, especially in FERWACOTAMO, which has a more localised structure, are more likely to represent themselves as defending their members from KCC directives and the police, even while advising members on how to comply with directives while suffering minimal disruption to their business. Only co-operative branch leaders seemed to have close ties to local (District, Sector and Cell) authorities, which they claimed to use as resources to support their members against higher-level authorities, and to avoid potential issues coming to the attention of the City Council. Individual motorcyclists' perspectives are, predictably the most varied. While some evince great trust in their branch leadership, especially in newly formed co-operatives, lacking a history of demonstrated corruption, most regarded their local co-op branches, their central organisations and the City Council and police as an undifferentiated mass, hostile to their livelihoods.

8 This is generally true in the urban zone, especially during the day. However, Kigali is marked by distinct 'zones of legality'; motari travelling away from the urban centre and into the rural fringes of the city are commonly less well documented and may be unlicensed; trips off the paved road may be undertaken without helmets, with multiple passengers and so on; late at night the law is felt to relax somewhat. Motari negotiate relationships with the law through corrupt payments and an acute awareness of where police officers are likely to be encountered. 
society' has long been a hallmark of Rwandan politics (Newbury, 200r), and certainly materially contributed to the production of reified, corporate, and increasingly violent ethnic identities as the basis of national politics between at least the late i950s and the outbreak of genocide in 1994 (Mamdani, 200I; Prunier, 1998). Since the end of the civil war in 1994, a substantially similar system of government has continued to operate (Reyntjens, 2004). While violent retribution in Rwanda against ethnic Hutus as génocidaires was largely confined to the period from 1994 to 1997 , and ethnic labelling officially banned in 2000, the RPF regime continues to show signs of, perhaps increasing, insecurity over its legitimacy and hold over the population. This has resulted both in the maintenance and extension of considerable powers and capabilities for surveillance and censorship at home - importantly in laws against 'genocide ideology' and 'divisionism', but also in mechanisms to register and formalise informal livelihoods - and an aggressive international campaign to present the 'New Rwanda' as a success story of post-conflict reconstruction and social harmony (Goodfellow \& Smith, 2013, p. 20; Reyntjens, 20II). These dual tendencies - to a certain paranoia, and an acute attention to presentation - converge at various points, for example in the government's tendentious rebuttal of allegations by the United Nations in 2012 that it sponsored M23 rebels in Eastern Congo and its immediate, televised deployment of Rwandan forces to offer visible support to the Congolese army.

This syndrome of 'transformative authoritarianism' (Straus \& Waldorf, 20II, p. 5) or, especially pertinent for my argument here, of a 'visionary authoritarian state' (Ingeleare, 2012, p. 394), which operates both through intimate forms of control and through the presentation of images of success, must be seen as a constitutive context to the material presented here. I dwell especially on the 'visionary' aspect of Rwanda's current politics.

\section{Motari and poverty-reduction}

There is little detailed research on Rwandan youth, and still less on urban youth. This is surprising, considering that Rwanda has one of the youngest populations in the world with a high rate of population growth, as well as a surprising rate of urbanization for a country with such a limited urban life (National Institute of Statistics, 201 2b). However, despite the huge significance of Rwanda's youth majority, the only major study of youth livelihoods and outlooks available is Marc Sommers' magisterial study Stuck: Rwandan Youth and the Struggle for Adulthood (2012). Sommers' research, conducted in 2006 is based on interviews with 335 young people in a sample of districts across the country, including urban areas (Sommers, 2012, p. 64).

Sommers' findings are in stark contrast to the upbeat tone of official Rwandan assessments of poverty and poverty reduction. Although current statistics show, encouragingly, that $36.4 \%$ of youth are poor and $18.3 \%$ extremely poor (National Institute of Statistics, 2012a), he finds that the social and economic position of Rwandan youth is dire overall, and especially problematic for youth in Kigali. He argues that rural youth face a crisis of adulthood. Shrinking landholdings, combined with central government policies 
on housing make building a iouse - the condition of marriage and socially acceptable adulthood - impossible for the bulk of youth. These dynamics push young people into the city in large numbers $-58 \%$ of Kigali's population was composed of recent migrants in 20I0-II (National Institute of Statistics, 2012b Table I.I.2). However, Kigali is no more hospitable to youth than the countryside, Sommers finds. Migrant and local youth remain unable to construct houses - building restrictions are even tighter in the city - and regulations against informal enterprise make most means of attaining a livelihood dangerous. Sommers paints a picture of exclusion, despair, violence, vulnerability and in all likelihood, rampant HIV infection amongst urban youth.

Motorcycle taxi drivers however, appear to buck the trend delineated by Sommers. ${ }^{9}$ Not only do established motorcyclists not suffer from poverty, many support large households, a significant proportion are married homeowners and while they acknowledge challenges they face in their work, they are overwhelmingly optimistic about their jobs. A credible estimate of motorcyclists' incomes, based on conversations with a large number of riders, is that motorcyclists can expect to earn between RWF I,000 and 5,000 per day, ${ }^{10}$ with an average take-home income of some RWF 3,000. Demographic data relating to motorcyclists' household size was captured in scheduled interviews with 62 motorcyclists. This showed an average household size of 4.5 people, slightly below the average for Kigali of 4.7 persons (National Institute of Statistics, 2012b). For the purposes of measuring poverty in Rwanda, the government defines poverty for an individual as consumption worth less than RWF II8,000 per year and extreme poverty as consumption less than RWF 83,000 per year (National Institute of Statistics, 2012c). By these measures, motorcyclists and their households are not poor. Calculated on the basis of a six-day working week, which the bulk of riders maintain, and using the average household size for the city, 4.7 people, we find that each member of a motorcyclists' family has access to almost RWF 200,000 per year, or around RWF 80,000 above the poverty line. ${ }^{11}$

More revealing than often inaccurate income estimates, however, are motorcyclists' own assessments of their situation. In interviews, I asked riders to compare their lives now with how they had lived before becoming motorcyclists. Overwhelmingly, respondents answered in a guardedly positive way: two thirds of respondents said that their lives had been improved by becoming motorcyclists.

The reasons motorcyclists gave for the improvement they identified in their living standards are instructive. The majority said that their lives today were better because now they had stable, relatively well-paid work. Many had come from backgrounds in

9 It is perhaps significant that while Sommers' research team conducted ${ }_{1} 65$ urban interviews, they did not speak to any motorcyclists (Sommers, 2012, pp. 64, 173).

Io At the time of my research one thousand Rwandan Francs (RWF) were worth slightly more than one pound sterling or about $\$ \mathbf{r} .50$.

II A national poverty line, of course, is problematic. Prices in Kigali are higher than in other areas of the country and rents especially can be very expensive. Motorcyclists regularly complain of hunger and poverty even though 'officially' they are not poor. For comparative purposes, these numbers would place motorcyclists approximately in $\mathrm{EICV}_{3}$ 's $\mathrm{Q}_{3}$ (National Institute of Statistics, 2012b). 
which they were chronically unemployed, or engaged in manual, casual, and unreliable forms of work. Another common comparison was between driving a motorcycle, which is skilled and does not involve using 'strength', imbalaga, and jobs such as carrying or building, which are unskilled and manual. Others pointed out that access to a motorbike gave them the freedom to work as they pleased, not under the close control of a boss. A common point of comparison here was the life of a houseboy, which riders regarded as demeaning. Motorcyclists value the reliability and relative dignity of what they do.

This impression was reinforced when motorcyclists compared their lives with others in different jobs. During interviews, I asked motorcyclists to compare their situation with other people doing different kinds of work. Motorcyclists were very realistic about their work. Most pointed out that their job was not as well paid as a job which an educated person could have. Nor did it make as much money as large, established businesses. However, these occupations were beyond their reach. When they compared their work with other 'basic' jobs - work that does not require education or training - they generally agreed that riding a motorcycle was a better job than others they were likely to be able to get. Riding a motorcycle is a 'profession', umwuga, rather than simply a 'job', akazi, and much better than temporary odd-jobs, ibiraka.

The overall picture here is of a poverty reduction success. Motari are youth; many of them are migrants. By Sommers' account, we would expect this group to be extremely vulnerable to exclusion and poverty. However, these results suggest that motorcyclists have effectively escaped from poverty and enjoy relatively secure and affluent livelihoods, enabling them to support sometimes large households above the poverty line. Although typical of Kigali's youth in many respects, motorcyclists are not poor and enjoy relatively high and stable incomes.

\section{How do motari escape poverty?}

Motorcyclists' success cannot be attributed to education or privileged backgrounds. Motorcyclists are not well educated, nor do they have remarkable backgrounds. Their relative affluence can only be attributed to their occupation: the success of motorcycle taxi drivers is an effect of their job, which is skilled, capital-intensive, and has a large and lucrative market. An explanation of the youth development success of the sector must begin with an analysis of how motorcyclists get access to motorcycles.

Most motari do not own the motorcycles they use. The i25cc TVS-manufactured machines most commonly used as taxis in Kigali cost around RWF 1.3 million on the road, which is beyond the reach of most riders who struggle to amass the RWF 200,000300,000 it costs to learn to drive legally. A few motari liquidate assets such as land or businesses to buy motorcycles, or else have access to commercial credit. FERWACOTAMO and SYTRAMORWA provide a small minority of the machines in use, either directly, or through supporting members to get loans. However, the overwhelming majority of the motorcycles used by motari in Kigali belong to small-scale local entrepreneurs.

At the root of motorcyclists' livelihoods is a network of informal deals between individual riders and these local entrepreneurs, called ababosi or 'bosses'. Bosses buy bikes 
which they either lend or lease to youths in exchange for a fee, usually RWF 5,00o per day, or between RWF 35,000 and RWF 30,000 per week. Relationships between riders and bosses may take the form of a rental agreement, in which case the daily fee simply allows the rider the use of the bike for a day, or a lease whereby the rider's daily fees constitute payment for the motorcycle, usually over 12-I4 months, after which it belongs to the rider. Most motorcyclists who own their own bikes acquired their first machines through such an agreement. While these agreements are often put in writing, the relationship between a rider and his boss is not formally regulated ${ }^{12}$ and almost all bosses remain small-scale investors in motos; few own more than one machine, and while a few formal-sector businesses invest in taxi-motos they represent a tiny minority of the total fleet.

In addition to relationships between motorcyclists and bosses, motari get work through highly informal deals amongst themselves. Not all motorcyclists have bosses or regular access to motorbikes. This is sometimes because a rider has recently parted company with a boss and is temporarily out of work. Others have bad reputations or suffer from alcohol or drug problems. Still others are new to the profession or lack the documents required to drive legally. These riders gather at motorcycle taxi stands, hoping to borrow motorbikes from friends and acquaintances. Motari who become tired will often lend a bike to one of these abarobyi, or 'fishermen', in exchange for RWF 5,000 for twelve hours or RWF 2,500 for six. In other cases, a rider with access to a bike from a boss will ride a twelve-hour day, before lending the bike to a friend for another twelve hours for RWF 5,000 . These relationships are normally well established and enable bikes to be profitably on the road twenty-four hours a day. Lending motorcycles in this way adds an extra layer of informality and complexity to motorcyclists' access to motorbikes.

\section{Undoing development: hostility to motari}

The relationship between motorcyclists and the authorities is strained and occasionally erupts into open confrontation. In the recent past it has become violent. Conflict between the City and motorcyclists was crystallised for motari by an event in 2006: Kigali City Council (KCC) banned motorcyclists altogether from the downtown area. One KCC official described the moto ban of 2006 as follows:

[We stopped motorcyclists] because of accidents - more accidents in the city, bad driving and at that time there was a big statistic of accidents... That's why we stopped it for a small period - like I think it was one week. But it helped in the change of mind, of disciplining them... 
Motorcyclists' recollections of the events of 2006 suggest that the ban was enforced with considerable levels of violence. One driver recalled the ban in the following terms:

It was in 2006. That time was a tough period. We had a communiqué saying, no motos - on the radio and the TV, saying no motos in Kigali, we don't want to see motos in Kigali. And then motari were shot because of violating that rule. And also, the police hit them with police cars. It was about two weeks, because we spent one week without working, and then the next week, we went back to the road [in violation of the ban]. So it was like that. Some of us kept working, but the police were hitting those motos. And the police also said to those people who take motos, 'if you take motos, we won't be responsible for your safety'... Then after that, the President, His Excellency, found that that was a problem, and he decided to bring us back onto the road.

The 2006 ban is emblematic of the relations between motari and the city. Nor, according to motari, has this hostility ended. Rather it has taken on new forms, most notably in new punitive measures which the police take against motorcyclists. In 20II, traffic police in Kigali began summarily impounding motorcycles implicated in a range of traffic offences. Machines were confiscated for 30 days, in addition to the levying of fines and often, motari complained, bribes. In 2012, traffic police could be seen at major intersections, stopping motari and confiscating their bikes. At the main city centre roundabout in the downtown area, it was not uncommon to see a police contingent guarding a collection of up to ten or fifteen confiscated machines.

A senior police officer explained that motorcycles were impounded for serious or repeat offences:

For a repeat offender - for someone who has committed a serious offence like... the guy's drunk, he's lively and probably he knocks someone... You find that all the offences have what that makes it big - a big offence, which relates to misconduct ... So this person would be charged for that and the motorcycle would be grounded for some time.

However, motari, co-operative leaders and more junior police sources were explicit in stating that this policy was not a sanction for aggravated offences, but a routine extralegal measure for controlling the number of motorcycles on the street. ${ }^{13}$ Motorcyclists missing documents, with defective lights or tyres, carrying passengers with luggage or disobeying road signs were all at risk of having their machines confiscated. These are offences normally referred to as contravention, which would normally attract a ticket and a fine - and which, motari insisted, were punished in this way when they were committed by the drivers of other vehicles. Motari regarded this as an example of victimisation at the hands of the authorities, as this rider makes clear: 
Most people disrespect taxi-moto. They disrespect moto, if you see how police will stop a car and a moto. With moto they will stop it and because it's small and light they take it. With a car they just write contravention. And they keep the moto for a month. And after that month - when you weren't working - you have to pay fines.

The extent of impoundment is considerable. A junior police officer claimed that 800 motorcycles, or around $7.5 \%$ of the total fleet in Kigali, were held at police headquarters when I interviewed him in July of 2012. Motorcyclists regard police intervention in their lives as a constant threat. One rider expressed a more general view when he said,

If you see today - the life of motari is not good, ça ne marche pas. Everyone wants motos - they are hunting motos.

While the ban of 2006 was short lived, many riders consider that current police actions are designed to have the effect of eradicating motorcycles from the city. Nor are drivers' concerns unwarranted. The Kigali Conceptual Masterplan (Oz Architecture and Kigali City Council, 2007) and the detailed plan for Nyarugenge District (Surbana Architecture, 2010) clearly envisage a city run without motorcycles. Moreover, FERWACOTAMO officials themselves suggested that they had plans to prevent new motari joining the profession as a measure to halt its growth and enable the ikimotari to be phased out, an aspiration shared both officially and in private by City officials.

Given Rwanda's stated commitment to poverty reduction, the very real challenges presented by Kigali's poor, and the poverty reduction success of the moto sector, why would KCC consider destroying a business which has such positive outcomes for the capital's vulnerable youth?

\section{The image of Kigali. Policy and 'reality'}

Here, we appear to face a contradiction. On one hand, the government of Rwanda is committed to poverty reduction. On the other, Kigali City Council, the Traffic Police, motorcyclists' organisations and other local manifestations of the Rwandan state pursue policies which are hostile to motari, despite the fact that the ikimotari is so successful in raising Rwanda's vulnerable youth majority out of poverty. ${ }^{14}$

One way of resolving this contradiction is to separate what happens in Rwandan development policy from its material double in Rwandan social life (Ingelaere, 2012). That is, to suggest that while there may be a contradiction at the level of actual socio-economic arrangements, this is in an important way irrelevant to the formation and implementation of Rwanda's development 'vision'.

I4 While it is true that the growth of the sector may undermine its capacity sustainably to deliver poverty reduction outcomes - limits to the growth of the ikimotari may be good for existing drivers - this is not the official justification for hostility to motos, which revolves around road safety. Nor is it easy to make a coherent account of why the government has enabled so many young men to gain driving licenses, which they want because of the income which driving offers, while at the same time pursuing a strategy which would seem to be aimed at limiting their ability to get that work. 
In making this suggestion, I follow a number of other scholars of Rwanda, notably Pottier (2002) and Ingaleare (2012), who argue that the direction and character of public policy in Rwanda is concerned less with outcomes and material realities, and more with the projection of imagery of particular kinds. These 'magical' images, shorn of direct reference to history and materiality, are the stuff of Rwandan politics in this account. ${ }^{15}$ Ingaleare is in agreement with both Pottier (2002) and Sommers (2012, see also Goodfellow \& Smith, 2013; Purdeková, 2011) that this separation between materiality and imagery is heavily influenced by the sense of revolutionary purpose exhibited by the ruling RPF party. Ingaleare acidly comments that 'the RPF must be seen as aiming to create the true postcolonial Rwanda.' That 'true' Rwanda is one free of the ethnic divisions and violence which marked the 'false' Rwanda created in the social revolution of 1959-62. It is a 'true' postcolonial nation insofar as ethnic division is attributed to continued colonial influence. However, this 'true' Rwanda depends on a paradoxical denial of the actual character of Rwanda's ethnically divided society, at least until 1994 and likely since.

This rejection of actual historical circumstance is surely related to the widespread insistence exhibited at every level of government that 'policy' cannot be wrong (Sommers, 2012; Purdeková, 20II). Failure is a reflection of the lack of commitment and bad mindset of the implementers, not the initial directive. Such rejection of material-historical circumstance in the pursuit of revolutionary goals allows the imagery projected by policy to trump the actual realities of social life. ${ }^{16}$

The shortfall between image and reality noted in Rwandan public policy in general is particularly significant in the context of the redevelopment of Kigali. As Goodfellow and Smith (2013) observe, the trajectory of Kigali from a glorified village, depopulated and devastated by civil war and genocide in 1994 to a 'model city' with security and amenities attractive to both domestic and international elites represents a significant achievement, one which runs against a trend amongst post-conflict cities which typically become centres of violence and insecurity long after (rural) conflicts have abated (Pearce, 1998; Rodgers, 2009). However, we can argue that Kigali is not only an elite enclave in an impoverished country: it is also systematically projected as an image which is very much at odds with the lives of most of its residents.

This observation is not specific to Kigali. Rakodi comments that the apparent 'failure' of Africa's cities 'emphasises the extent to which their built environments fall short of the visions of the powerful, rather than how economic and social organisation

Note that a separation between the linear, one-thing-after-another historical-material accounts and images, in which all of the elements are present at the same time is consistently identified by theorists of imagery, especially photographs and other profoundly 'mimetic' media (Flusser, 2000; Sontag, 1977; Taussig, 1993). The image is in a sense a device by which history is cut off and restarted, or by which history can be denied altogether as the basis of experience and subjectivity (Harvey, 1989; Jameson, 1984).

I6 Note that this reading is somewhat different to Goodfellow and Smith's account of securitisation in Kigali, which suggests that problems are 'deferred' $(2013$, p. 22) by the construction of an image of security, perhaps to resurface later. While I agree that it is likely that an emphasis on the rhetorical and imagic works to store up problems for the future, I would argue that the dynamic of these policies is less deferral than masking and denial. 
actually functions to accommudate population growth and support the daily lives of their residents' (2006, p. 312), a concern gaining currency in the literature on the continent's urban centres (see Simone, 2004). For Rakodi, diagnoses of failure are based not on what actually happens in the city, the actual lives of its residents, but on judgements of the built environment framed in relation to images of the 'modern' city which have persisted since the late colonial period (see Freund, 2007), despite the increasing difficulty ever of realising them. Here the 'problem' of African cities does not appear in relation to the actual character and functioning of urban life (which may, of course, be deeply problematic on its own terms) but relative to authoritative images of urban life elsewhere - the 'modern', 'efficient' cities of the West and East Asia.

Furthermore, images of the 'efficiency' of cities in general can be regarded as existing at one remove from the actual functioning of urban life. Scott (1998) argues that purportedly efficient, modernist design is based on aesthetic and not functional principles proceeds from the observation that cities, and indeed all human social formations, are very complicated and never static - yet they function effectively in ways which are perhaps impossibly difficult to understand. In order to plan a city, a certain constitutive reduction is required at the point at which a plan is conceived and made. Only through such a reduction can the plan achieve any kind of overall sense or 'legibility'. The activity of rendering urban life legible in a plan through reduction depends on a set of principles on which that reductive activity is to take place. These cannot proceed from the nature of urban life as such, because a functioning urban community is too complex and has too many shifting and cross-cutting norms and conventions to be 'planned'; actual urban life is organic and unplanned (Scott's inspiration here is Jacobs, 196r). Therefore the reductive principles on which an urban plan is founded serve simply to project an image of efficient (simplified) operation which has no necessary relation to actual urban life.

Such images, Harvey suggests, have become an important trope in intellectual and artistic production - and filter into the conventions of urban design through the 'institutionalized commercialization of a more or less permanent spectacle' (Harvey, I989, p. 90). ${ }^{17}$ Harvey's point is that contemporary cities are constructed less as functioning urban habitats than as advertisements for themselves - where the image of a pleasant place to live may be one component of a city's self-presentation. Ironically, contemporary 'mixed-use' developments which respond to the kinds of critique Scott (1998) articulates drawing on Jacobs ( 1961 ), now the norm, become by this logic not liveable urban spaces as such, but images of liveability. At the core of the city is the public projection or image (Harvey's 'spectacle') of qualities which suggest that it is distinctive and desirable.

17 Harvey locates this trend 'now' in his 1989 book. Nevertheless, analyses of the development of cities in the period before the economic shifts Harvey identifies, for example Brasília (Holston, 1989) and Cairo (Mitchell, I988) display very similar dynamics in their equation between appearance and (desired) function. Geertz's (1980) observation that states, and perhaps other organisations, exist essentially as self-representations, is perhaps instructive here. 
Consider in this context the dream articulated in the Kigali Conceptual Masterplan:

'...a "hub" of Africa ... a catalytic leader in African development: a regional center of transportation and economic vitality, which will leapfrog into the mid 21st century through technological innovation' (Oz Architecture and Kigali City Council, 2007, p. xiii).

Crucial to this statement are the qualities of Kigali: catalytic, vital and innovative. In the context of EDPRS and the drive to attract foreign investment, these qualities become significant as a lure for investors. The city must become vibrant in order to attract the businesses that will make it a regional hub and fulfil its development objectives. More precisely, the city must perform the qualities alluded to in the Masterplan in order to attract the investment which might render them concrete.

These trends are equally apparent in the detailed Masterplan for Kigali's Nyarugenge district, which, for each Sector, proposes a showcase development to emphasize the qualities of the various areas of the district and to project the overall image mandated by the plan. The relevant plan for Nyakabanda Sector reads as follows:

As part of Nyamirambo Regional Centre, the southern part of the commercial strip along Avenue de la Nyabarongo is proposed to be developed as a mix [sic] use area. The boulevard along this stretch is proposed as a distinctive street with landscaped pedestrian walkways lined with low-rise vibrant mix [sic] use, commercial, office and residential developments and intimate street-level facilities on both sides. Existing public facilities are proposed to be retained, upgraded and integrated with new facilities to give a distinctive identity to the development (Surbana Architecture, 2010, pp. 8-12 emphasis added).

Note the emphasis on qualities: distinction, intimacy and the creation of a unique identity. It is the presentation of the city in this manner which is intended to attract investment; only through that investment can Kigali become the 'catalytic hub' envisaged in the Masterplan.

Note also that, once the city is understood in this way, it becomes almost impossible to distinguish the spectacular or performative from the functional. The Nyarugenge Masterplan dwells at great length on the possibilities of advanced ecological waste-water treatment and innovative public transport solutions, as well as proposing an expansion of parks and facilities for cycle commuting. Regardless of the potential utility of these aspects of the plans, it is impossible to avoid the suspicion that each of these innovations is in fact gesture towards the image of a dynamic, vibrant and globally competitive regional catalyst which Kigali seeks to project through its redevelopment. Once the city has become a spectacle, every aspect of it appears to project an image: hence, Goodfellow and Smith note that 'Kigali's status as a successful post-conflict development story is itself a political resource that the government draws on for legitimacy and credibility at home and abroad' (2013, p. 20). Every aspect of Kigali, from this perspective, is intended to demonstrate the qualities of the city, the regime and Rwanda as an investment destination. 
On the basis of this argument, we can make a series of linked propositions about the kind of context in which the 'contradiction' between the poverty reduction successes of the ikimotari and government hostility to the profession emerges. First, this putative contradiction appears in the context of urban redevelopment which, both in general and in the specific case of Kigali, can be regarded as an exercise in image-creation rather than primarily concerned with actual urban life (Harvey, 1989; Jameson, 1984; Scott, 1998). Second, this is a trend in African urban development, in which models of efficient cities, rather than attention to the social lives of city-dwellers are used as the yardstick of success (Rakodi, 2006; Simone, 2004). Third, these dynamics are likely to be intensified in Rwanda, whose government is widely seen to attend more to the rhetorical presentation of policy than to the realities of its implementation and whose 'magical thinking' systematically disconnects 'vision' from social reality (Ingelaere, 2012; Pottier, 2002).

\section{Performance and security}

Why does a perspective such as the one I have just outlined suggest that there is no contradiction in the relation between motorcyclists and the city? And what does this tell us about the nature of poverty reduction and, perhaps, development in Rwanda and maybe beyond? These questions hinge on the status of 'material reality' (such as the 'material reality' of motari incomes) in a context governed by the production of, and compliance with, images of various kinds. ${ }^{18}$

One answer to these questions is by way of an appeal to theories of performativity. Judith Butler's analysis of sex, gender and sexuality is useful in this regard. Butler asks, given that empirically, human sexuality stands in a very varied relation to human bodies and pleasures, why are only certain sex acts and sexual relationships regarded as 'natural', while others appear to be 'deviant'? The variability of human sexuality immediately discounts the argument that certain kinds of sex are actually 'unnatural', so the question becomes one of why and how nature is constituted in such an exclusionary way. Butler argues that conventional representations of bodies, gender relations and sexualities proceed from the nature of sexually marked human bodies, which are regarded as causing gender relations and particular forms of (heterosexual) desire, 'naturally' consummated in heterosexual sex. However, she contends that in fact, given that sex takes place in an already existing social environment, 'nature' itself is not prior to sex acts. Rather, she argues that sexual pleasure defines certain bodily relations (gender), which in turn are parsed for 'nature' after the fact. Nature is simply the label applied to certain orderings of sex-desire and bodies. Sex is 'performative' in the sense that, following Austin's analysis of performative speech acts, it is not motivated by and does not refer to an existing reality or 'nature' but creates it, much as a marriage is created by the declaration of a priest. ${ }^{19}$ The 'naturalness' of sexuality is a product of judgement in terms of images of nature, not the

I8 Note that at issue here is essentially the imaginary relation between people and their conditions of existence, or ideology, in the terms identified by Althusser (2008; see also Butler, 1997).

I9 In their shared deployment of Austin's (1975) account of performative speech acts, Butler and Ingaleare are broadly in agreement. 
logical corollary of any universal 'facts of life'. In Butler's analysis, the performance of natural sex is made and judged in terms of a prior image of nature, not the materiality of sex.

My claim here is that we might understand Kigali's development and the place of motari in it, by approaching it in terms of the imagery the city seeks to project, and not in terms of material economic and social outcomes. In short, I am suggesting that development is constituted by those images, and not, in fact, by the materiality of raising people out of poverty or, given that poverty reduction and development are not co-extensive, any other 'development activity'. Put another way, I am arguing that poverty reduction must present itself as a component of that image to be recognised as a valid instance of development, much as in Butler's theory a physically sexed body must nevertheless enact its gender in order to be recognised as 'natural'.

These dynamics are apparent in the way motari are integrated into the spectacle-city through an apparatus of 'security' and co-operative development which projects the image of a modern, efficiently regulated sector appropriate to the city. Strikingly, since 20I I, the city council, in partnership with FERWACOTAMO, has worked to demarcate the parking places for motorcycles, to prevent disorderly parking by means of white lines. These marked parking places were being equipped with numbered signs in 2012. It is not clear that such interventions can make a material difference to the functioning of the moto sector, but they certainly have an impact on its aesthetics.

Similarly, the sector is the object of efforts by the motorcyclists' organisations FERWACOTAMO and SYTRAMORWA to create security. Security, umutekano, means in this connection being able to identify motorcyclists and their machines and ensuring that they are properly licensed. Since 2012, FERWACOTAMO and SYTRAMORWA have established databases intended to contain the personal details of their members, the identifying numbers and owners of the machines that they ride, their co-operative affiliation, and so on. ${ }^{20}$ These databases are linked to a system of alphanumeric codes which are printed on the gillets which motari are required to wear, and accompanying documents. These codes are intended to identify riders individually and show their co-operative affiliation and the area in which they work. The organisations' explicit aim in doing so is to establish a simplified, one-to-one relationship between a rider, his machine, his co-operative and his place of work. These security measures are meant to make it possible to find and identify any rider at any time.

My argument here should not be taken to imply that physical security is either unimportant for Rwandans, or that it is illusory: it is neither. Nor is it fair to suggest that the Rwandan government and KCC specifically are not genuinely committed to security. As such, I do not dispute Goodfellow and Smith's claim that between the I 990 and the present day, the moto sector, a 'problematic industry' was 'turned to the government's advantage, incorporating motorcyclists into the city surveillance mechanisms and local development plans' (2013, p. 19). I simply suggest that it is also important to interrogate security for its aesthetic effects, the kinds of performances and judgments that it enables, especially from a non-elite perspective. 
The actual social organisation of the moto sector, however, subverts these measures. ${ }^{21}$ The informal networks by which motari gain access to motorbikes make it enormously difficult to establish simple relationships between a rider, a machine and its owner. Indeed considering the importance of these shifting relationships and personal deals to motari livelihoods, it seems not unreasonable to claim that were such a simplified, tabulated grid of connections to be established, the sector simply could not function. In this regard, motari appear as a group to be resistant to 'security' imagined as a particular form of knowledge and vision in the sense that they are difficult, if not impossible, to integrate into these forms of 'panoptic' (Foucault, 1975) knowledge.

However, motari do now appear as a group which should be represented by the tabulation of people to render them legible and accessible to scrutiny (c.f. Mitchell, 1988). This is an image of an order, which cannot in fact be achieved given the structural constraints of the sector, figured in the numbered vests which motorcyclists wear as much as in their marked parking bays (c.f. Ingelaere, 2012). The development and securitisation of the sector is therefore in a sense produced as a simulacrum: a projection created out of clothing, tables of data and road markings through which an entirely different and differently ordered form of social life moves and in whose terms it can be judged. ${ }^{22}$ The difference between the realities of motari livelihoods and the imagery of order created by the security apparatus serves to constitute motari as deviant: all of their actions reiterate or perform their deviant status within the spectacle of the securitised 'model city'. On this basis, they can and do become the objects of harassment and 'discouragement' by the authorities.

The poverty reduction success of the ikimotari is therefore undone or invisible because motari are so difficult to accommodate to the imagery of Kigali, the modern, dynamic (future) city. From a strictly empirical perspective, where poverty reduction can be seen based on an analysis of livelihoods, and the effects of increasing incomes, there is a contradiction between the economic impact of the ikimotari and the attitudes of the authorities towards the sector. However, where the 'reality' of development is governed by images, as I have suggested is the case in Kigali, the materiality of poverty reduction is irrelevant: development is constituted as a performance, and even people who are less poor as a result of their work will be vilified where that work interferes with the aesthetics of official visions. sations' security measures are undermined. It is also important to bear in mind that 'resistance' is inherent in this system both in the sense of deliberate disobedience to rules and as the unintended consequence of programmes of domination (Foucault, 1995). The various contexts and modalities in which the 'resistance' of motari to the authorities is constituted will be the subject of another publication. 


\section{Conclusions}

In this paper, I have argued that the development of Kigali, and perhaps development in Rwanda as a whole, exists more in the projection of images of development, enforcing performances of certain kinds from citizens, than in the material, economic realities of poverty reduction. The apparent contradiction between the material poverty reduction success of Kigali's motari and the authorities' hostility towards them is therefore no contradiction, in the sense that development has little connection to economic outcomes; actual poverty reduction is less important than compliance with images of development, in this case, images of the 'modern', 'global' city of Kigali. Motorcyclists, for all their poverty reduction capacity are excluded from the development of the city because they do not fit the image which the city council aims to project. In short, the imagery of development precludes their activities from being recognized as legitimate instances of development activity, and exposes them to harassment and violence as a result. Likewise, poverty reduction activity (as a concrete issue of money in pockets) is of a different order to development activity (as a question of image and performance). ${ }^{23}$ This in turn suggests that, in keeping with the 'spectacle city' of Kigali, development itself here becomes a simulacrum, a performance to be parsed by observers for acceptable values and legible designs.

While this suggestion is in keeping with other interpretations of government activities at all levels in Rwanda, we should also ask to what extent it is applicable to development activities in other contexts. While development should not be understood as a monolithic structure (Gardener \& Lewis, I999; Green, 2003; Mosse, 2005), phrased broadly it is fair to say that development mobilises considerable resources for social change (Rist, 2008). Given that development makes a difference - not necessarily the difference intended, but a difference nonetheless (Ferguson, 1990) - the questions of what 'counts' as development, on what terms, and in what context are very significant ones. The capacity to brand or recognize certain activities as 'development' confers legitimacy, funding and support on particular modes of political activity, as the rise and fall of techniques such as structural adjustment, micro-finance (Bateman, 2010; Rankin, 2002, 2008), participatory poverty assessment and project planning (Green, 2003; Mosse, 2005) - and latterly poverty reduction, demonstrate. Moreover, we are familiar with the idea that development is shaped by bureaucratic systems (Ferguson, 1990) and discursive regimes (Escobar, 1995) which cut development activities off from the world on which they purport to work. If development systematically fails, as Ferguson long ago suggested, to what extent is it because development projects are more geared to the performance of development's imagery than to concrete intervention in social lives?

23 This is not to suggest that one is more 'real' than another. A useful analogy might be Barthes' exploration of myth. In his account, while everyday meaningful activity proceeds by means of quotidian signs (signifying objects in the world), myth operates as a metalanguage, taking constituted signs as signifiers of other meanings and thus constructing higher-order ideological constructs. It would be a mistake, however, to take Barthes' view as implying that myth is 'less real' than everyday discourse simply because it is logically posterior. Quite the contrary: for Barthes, the reproduction of social life as we know it depends on the organising power of the myths which organise it. All that is at issue is the signifying capacity of the terms in use, not their relative 'reality'. 
Drawing the analogy with Butler's ideas about gender and sexuality implies that the concept of 'development' as deployed in Kigali is constituted through repetitive performative actions. This raises the question of whether all development is (like gender) constructed in this way and not what (if anything) 'real' development actually means. In fact the 'reality' of development in this analysis would vanish in favour of its performance, while it's material-economic effects, like motari incomes in Kigali, become irrelevant to the judgment of outcomes - an analysis which chimes with anthropological attitudes to development's failure. It would be rash of me to make a global claim on the nature of development here. However, it is worth noting the ways in which such an approach would move beyond questions of discourse and the inner workings of development organisations to interrogate the interface between development, its implementers and putative beneficiaries to reveal its effects on the performance of everyday politics.

\section{Acknowledgements}

I am grateful to Nicolas Argenti and Isak Niehaus for their useful comments on an earlier draft of this paper, as well as the invaluable input of three anonymous referees for Afrika Focus. The research on which this paper was based was funded by Brunel University's BRIEF scheme.

\section{References}

Althusser, L. (2008). On ideology. London; New York: Verso.

Asiimwe, B. (2012, February 6). Rwandans rush to own driving permits. The New Times. Kigali.

Austin, J.L. (1975). How to do things with words. Oxford: Clarendon Press.

Bateman, M. (2010). Why doesn't microfinance work? The destructive rise of local neoliberalism. London; New York: Zed Books.

Butler, J. (1990). Gender trouble: feminism and the subversion of identity. New York: Routledge.

(1995a). Contingent foundations. In Feminist contentions: a philosophical exchange (pp. 35-58). New York: Routledge.

(1995b). For a careful reading. In Feminist contentions: a philosophical exchange (pp. 127-I44). New York: Routledge.

(1997). The psychic life of power: theories in subjection. Stanford: Stanford University Press.

Craig, D., \& Porter, D. (2003). Poverty Reduction Strategy Papers: A New Convergence. World Development, 3I(I), 53-69.

Escobar, A. (1995). Encountering Development: The Making and Unmaking of theThird World. Princeton: Princeton University Press.

Ferguson, J. (1990). The anti-politics machine: "development," depoliticization, and bureaucratic power in Lesotho. Cambridge: CUP Archive.

Flusser, V. (2000). Towards a philosophy of photography. London: Reaktion Books.

Foucault, M. (1995). Discipline and punish: the birth of the prison. New York: Vintage Books.

Freund, B. (2007). The African city. Cambridge: Cambridge University Press.

Gardener, K., \& Lewis, D. (1999). Anthropology, development and the post-modern challenge. London: Pluto Press.

Geertz, C. (1980). Negara: the theatre state in nineteenth-century Bali. Princeton, N.J.: Princeton University Press. 
Goodfellow, T., \& Smith, A. (2013). From urban catastrophe to "model" city? Politics, security and development in post-conflict Kigali. Urban Studies, 50(15).

Gready, P. (2010). "You"re either with us or against us': Civil society and policy making in post-genocide Rwanda. African Affairs, 109(437), 637-657.

Green, M. (2003). Globalizing Development in Tanzania. Critique of Anthropology, 23(2), 123-143.

Harvey, D. (1989). The condition of postmodernity: an enquiry into the origins of cultural change. Oxford; Cambridge, Mass.: Blackwell.

Holston, J. (1989). The Modernist City: An Anthropological Critique of Brasilia. Chicago: University of Chicago Press.

Ingelaere, B. (2012). From model to practice: Researching and representing Rwanda's "modernized" gacaca courts. Critique of Anthropology, 32(4), 388-414.

Jacobs, J. (I96I). The death and life of great American cities. New York: Random House.

Jameson, F. (1984). Postmodernism, or the Cultural Logic of Late Capitalism. New Left Review, (146), 53.

Kimenyi, C. (2012). Rusimbi Charles ashenye amakoperative, Meya Ndayisaba arebera. Ingenzi, p. 7. Kigali.

Mamdani, M. (2001). When victims become killers : colonialism, nativism and the genocide in Rwanda / Mahmood Mamdani. Oxford: James Currey.

Mitchell, T. (1988). Colonising Egypt. Cambridge: Cambridge University Press.

Mosse, D. [Main author]. (2005). Cultivating development: an ethnography of aid policy and practice. London: Pluto Press.

National Institute of Statistics. (2012a). EICV Thematic Report: Youth. (201 2b). Third Integrated Household Living Conditions Survey $\left(\mathrm{EICV}_{3}\right)$. (2012C). The evolution of poverty in Rwanda from 2000 to 2011: results from the household surveys (EICV).

National Poverty Reduction Programme. (2002). The Government of Rwanda Poverty Reduction Strategy Paper.

Newbury, D. (2001). Precolonial Burundi and Rwanda: Local Loyalties, Regional Royalties. The International Journal of African Historical Studies, 34(2), 255.

$\mathrm{Oz}$ Architecture and Kigali City Council. (2007). Kigali Conceptual Masterplan.

Pearce, J. (1998). From civil war to "civil society": has the end of the Cold War brought peace to Central America? International Affairs, 74(3), 587-615.

Pottier, J. (2002). Re-imagining Rwanda conflict, survival and disinformation in the late twentieth century. Cambridge; New York: Cambridge University Press.

Prunier, G. (1998). The Rwanda crisis: history of a genocide. London: Hurst.

Purdeková, A. (2011). "Even if I am not here, there are so many eyes": surveillance and state reach in Rwanda. The Journal of Modern African Studies, 49(03), 475-497.

Rakodi, C. (2006). Relationships of power and place: The social construction of African cities. Geoforum, 37(3), 312-317.

Rankin, K. N. (2002). Social Capital, Microfinance, and the Politics of Development. Feminist Economics, 8(I), I-24.

(2008). Manufacturing rural finance in Asia: Institutional assemblages, market societies, entrepreneurial subjects. Geoforum, 39(6), 1965-1977.

Republic of Rwanda. (2000). Vision 2020.

(2007a). Economic Development and Poverty Reduction Strategy.

(2007b). Law No 50/2007 of 18/09/2007 determining the establishment, organisation and functioning of cooperative organisations in Rwanda.

Reyntjens, F. (2004). Rwanda, ten years on: From genocide to dictatorship. African Affairs, 103(4II), 177-210.

(2011). Constructing the truth, dealing with dissent, domesticating the world: Governance in post-genocide Rwanda. African Affairs, Iro(438), I-34. 
Rist, G. (2008). The History of Development: From Western Origins to Global Faith (3rd Revised edition.). New York: Zed Books Ltd.

Rodgers, D. (2009). Slum wars of the 21st Century: gangs, mano dura and the new urban geography of conflict in Central America. Development and Change, 40(5), 949-976.

Rwanda Utilities Regulatory Agency. (2011). Key statistics information: transport of persons (road transport).

Scott, J.C. (1998). Seeing like a state: how certain schemes to improve the human condition have failed. New Haven: Yale University Press.

Simone, A.M. (2004). For the city yet to come: changing African life in four cities. Durham: Duke University Press.

Sommers, M. (2012). Stuck: Rwandan youth and the struggle for adulthood. Athens; Washington, D.C.: University of Georgia Press ; published in association with the United States Institute of Peace.

Sontag, S. (1977). On photography. New York: Farrar, Straus and Giroux.

Stern, D. (2000). The return of the subject? Power, reflexivity and agency. Philosophy and Social Criticism, 26(5), I09-122.

Straus, S., \& Waldorf, L. (20II). Seeing like a post-conflict state. In Remaking Rwanda: State Building and Human Rights after Mass Violence (pp. 3-22). Madison: University of Wisconsin Press.

Surbana Architecture (2010). Detailed Master Plan Report for Nyarugenge District.

Taussig, M.T. (1993). Mimesis and alterity: a particular history of the senses. New York: Routledge.

Uvin, P. (1998). Aiding violence: the development enterprise in Rwanda. Kumarian Press.

(200I). Difficult choices in the new post-conflict agenda: the international community in Rwanda after the genocide. Third World Quarterly, 22(2), 177-189. 